\title{
Inflammasome polymorphisms confer susceptibility to sporadic malignant melanoma
}

\author{
Deepti Verma, Cecilia Bivik, Ensieh Farahani, Ingrid Synnerstad, Mats Fredrikson, \\ Charlotta Enerbäck, Inger Rosdahl and Peter Söderkvist
}

\section{Linköping University Post Print}

N.B.: When citing this work, cite the original article.

This is the authors' version of the following article:

Deepti Verma, Cecilia Bivik, Ensieh Farahani, Ingrid Synnerstad, Mats Fredrikson, Charlotta Enerbäck, Inger Rosdahl and Peter Söderkvist, Inflammasome polymorphisms confer susceptibility to sporadic malignant melanoma, 2012, Pigment Cell \&amp; Melanoma Research, (25), 4, 506-513.

which has been published in final form at:

http://dx.doi.org/10.1111/j.1755-148X.2012.01008.x

Copyright: Blackwell Publishing http://www.blackwellpublishing.com/

Postprint available at: Linköping University Electronic Press http://urn.kb.se/resolve?urn=urn:nbn:se:liu:diva-79688 
Inflammasome polymorphisms confer susceptibility to sporadic malignant melanoma

Deepti Verma ${ }^{1 \# *}$, Cecilia Bivik ${ }^{2 \#}$, Ensieh Farahani ${ }^{1}$, Ingrid Synnerstad ${ }^{2}$, Mats Fredrikson ${ }^{3}$, Charlotta Enerbäck $^{2}$, Inger Rosdahl ${ }^{2}$ and Peter Söderkvist ${ }^{1}$

${ }^{1}$ Division of Cell Biology, ${ }^{2}$ Division of Dermatology, ${ }^{3}$ Division of Occupational and Environmental Medicine

Department of Clinical and Experimental Medicine, Faculty of Health Sciences, Linköping University, SE-581 85 Linköping, Sweden

\#Both authors contributed equally to this work

*Corresponding author: Deepti Verma

Division of Cell Biology

Faculty of Health Sciences, Linköping University

SE-581 85 Linköping, Sweden

Phone: +4610103 3489, Fax: +46101031718

E-mail: deepti.verma@liu.se

Word count: 4886

Figures and tables: 5

The authors declare no conflict of interest 


\section{Summary}

Genetic variants of $N L R P 3$ and $N L R P 1$ are known to modulate levels of pro-inflammatory cytokine Interleukin (IL)-1 $\beta$. The purpose of this study was to investigate the association of NLRP3/NLRPI polymorphisms with susceptibility and clinical features of malignant melanoma in a Swedish casecontrol study. Common variants in NLRP3/NLRP1 were investigated in sporadic malignant melanoma patients and healthy controls followed by analysis using logistic regression. NLRP3 variant (rs35829419) was significantly more common in male patients than in controls (OR 2.22, CI 1.273.86). Upon stratification, significant association to nodular melanoma was observed (OR 2.89, CI 1.33-6.30) which intensified in male patients (OR 4.03, CI 1.40-11.59). The NLRPI variant (rs12150220) was significantly more common in fair skinned female patients (OR 1.85, CI 1.04 -3.33) and showed strong associations with nodular melanoma (OR 6.03, CI 1.33-25). Our data suggests that NLRP3/NLRP1 polymorphisms are associated with melanoma susceptibility; these findings warrant validation in other independent populations.

\section{Significance}

An essential role of the pro-inflammatory cytokine IL-1 $1 \beta$ in tumor invasiveness and angiogenesis has previously been demonstrated. NLRP3/NLRP1 inflammasomes are IL-1 $\beta$ producing platforms that regulate inflammation. We report an increased susceptibility to sporadic malignant melanoma in the presence of common polymorphisms in the inflammasome genes. A particularly strong association was observed to nodular melanoma. Genetic alterations in the inflammasome genes might through dysregulations in IL-1 $\beta$ production result in increased susceptibility to melanoma.

\section{Key words:}

Inflammasome, NLRP1, NLRP3, CIAS1, SNP, melanoma, IL-1 $\beta$ 


\section{Introduction}

NACHT-LRRs (NLRs) are a group of cytosolic receptors that recognizes intracellular microbial products as well as metabolic stress (Schroder and Tschopp, 2010). The NLR family includes 22 members and has a key role in regulation of inflammation and apoptosis (Schroder and Tschopp, 2010). The NLRs, NLRP1 (also termed NALP1) and NLRP3 (NALP3 or Cryopyrin) upon activation bind to an adaptor protein ASC to form an inflammatory complex termed the inflammsome, which cleaves pro-interleukin (IL)-1 $\beta$ and pro-IL-18 to mature and biologically active IL-1 $\beta$ and IL-18 (Fig.1) (Martinon et al., 2002, Agostini et al., 2004). Another adaptor comprising a function-to-find (FIIND) and caspase-activation and recruitment domain (CARD), termed CARD-8 (TUCAN or Cardinal) (Pathan et al., 2001), is postulated to be a binding partner of NLRP3, whereas its binding is not required by NLRP1, which already contains a C-terminal FIIND-CARD domain.

Missense mutations in the NLRP3 gene lead to familial periodic fevers, where symptoms arise from excess of IL-1 $\beta$ and accordingly, blockade of IL-1 $1 \beta$ effectively ameliorates the symptoms (Hoffman and Simon, 2009). More recently, a single nucleotide polymorphism (SNP) in NLRP3 (rs35929419), in combination with $C A R D-8$ polymorphism (rs2043211) have been associated with chronic inflammatory conditions (Verma et al., 2008, Kastbom et al., 2008, Schoultz et al., 2009, Roberts et al., Roberts et al., 2011). The CARD-8 protein is additionally suggested to be a negative regulator of caspase-1-mediated IL-1 $\beta$ regulation and NF- $\mathrm{KB}$ activation (Razmara et al., 2002, Fontalba et al., 2008). Another SNP in NLRP3 (rs10733113), located downstream of the NLRP3 gene, has been shown to regulate NLRP3 expression and IL-1 $\beta$ levels, and has recently been implicated in Crohn's disease (Villani et al., 2009). NLRP1 SNPs rs12150220 and rs6502867 have been reported to be associated with susceptibility to vitiligo (Jin et al., 2007b), an autoimmune disease affecting the melanocytes in the skin, where patients are reported to have elevated serum IL-1 $\beta$ levels (Tu et al., 2003).

Several recent reports describe the importance of inflammatory microenvironment in the risk of tumor initiation and progression (Coussens and Werb, 2002, Mantovani et al., 2008, Clevers, 2004, Coussens and Werb, 2001). Tumors secrete pro-inflammatory cytokines into the surroundings (Okamoto et al., 2010), which accelerate tumor development and progression in a number of ways e.g. by inducing proliferation and survival of malignant cells, by promoting angiogenesis and metastasis, and by altering responses to chemotherapeutic drugs (Mantovani et al., 2008). The molecular mechanisms linking inflammation and carcinogenesis, however, still remain to be clarified. Malignant melanoma (MM) originates from the pigment-producing melanocytes in epidermis and is the most severe type of skin cancer. Melanoma often displays an aggressive behavior with early metastases and its incidence increases faster than any other cancer type among fair skin population worldwide (Diepgen and Mahler, 2002, Lens and Dawes, 2004). The survival rate of melanoma patients is directly related to 
early detection and treatment and hence the search for genetic markers of disease risk is of continuing medical interest.

The present study investigates the significance of five inflammasome-related SNPs; rs35829419 and rs10733113 in NLRP3, rs6502867 and rs12150220 in NLRP1, and rs2043211 in CARD-8, in susceptibility and progression of MM. 


\section{Material and methods}

Study subjects

This study was approved by the Regional Ethics Committee at the Linköping University, Linköping, Sweden. 258 patients ( $53 \%$ females, $47 \%$ males, $\geq 18$ years) diagnosed with sporadic MM in the skin were included in the study. The patients were recruited from dermatology clinics in Southeastern region of Sweden (Linköping, Norrköping, and Kalmar). The mean age at inclusion was 59 years $( \pm 14$ years, range 23-87 years). A detailed description of the study subjects is listed in Table I. The mean age of the melanoma patients at the time of diagnosis was 55 years ( \pm 15 years, range 18-86 years). The skin type was classified according to Fitzpatrick (Fitzpatrick, 1988) and grouped in sun-sensitive (I and II) and less sun- sensitive (III and IV) skin types. The eye color of the melanoma patients was divided into two groups, blue/green and brown/mixed and hair color into blond/red and brown/black. Histopathological types of melanoma were in the following categories: superficial spreading melanoma (SSM), nodular melanoma (NM), lentigo malignant melanoma (LMM), acro-lentiginous melanoma (ALM), and melanoma in situ, and the Breslow thickness was grouped into $<2$ and $\geq 2$ $\mathrm{mm}$. Tumor location was registered using a schematic body chart as previously described (Synnerstad et al., 2004) and was classified into sun exposed (D,G,I,K,L,M,N) and rarely/ or not-sun exposed $(\mathrm{C}, \mathrm{H}, \mathrm{J})$ areas.

The control population comprised 792 healthy individuals (50\% females, 50\% males) with mean age of 54 years ( \pm 17 years, range $20-80$ years), randomly collected from the population register from the same geographic region as the patients with sporadic MM (Table I).

\section{Genotyping}

Genomic DNA was isolated from blood using the DNA blood maxi kit from Qiagen (Hilden, Germany). The rs35829419 and rs10733113 in NLRP3, rs6502867 and rs12150220 in NLRP1, and rs2043211 in CARD-8 were genotyped using TaqMan® SNP Genotyping assays (C_25648615_10, C_30713847_10, C_11708080_1, C_29222211_20, and C_1600653_10) respectively), according to the manufacturer's recommendations (Applied Biosystems, Foster City, CA). All analyses were performed in an ABI Prism 7500 Sequence Detection System, using the SDS 2.3 software for allelic discrimination (Applied Biosystems).

Statistical analysis 
The STATA v. 10 (Stata Corp., College Station, TX, USA) statistical package was used to analyze the results. A comparison between cases and controls was performed with logistic regression analysis. Results are expressed as odds ratio (OR) with a corresponding 95\% confidence interval (CI). Logistic regression was also used for calculations of the interactions between genes by using linear combinations of the coefficients of the variables. The variables were included one by one, together with the cross product term. The combination of variables was calculated by adding the coefficients and translated into an OR. 


\section{Results}

In the present case control study, the SNPs rs35829419 and rs10733113 in NLRP3, rs2043211 in $C A R D-8$, and rs6502867 and rs12150220 in NLRPI were studied in 258 patients diagnosed with sporadic MM and 792 controls. Both cases and controls were from the Southern part of Sweden. The description of the study subjects and stratifications of phenotypic features and melanoma characteristics are detailed in Table I and the genotype distributions are presented in Table II. All the SNP frequencies were found to be in Hardy-Weinberg equilibrium.

$N L R P 3$ and $C A R D-8$ polymorphisms in patients with sporadic MM

No association was detected between the NLRP3 rs35829419 and the overall risk for developing MM (Table III). Owing to the small numbers (1\% in cases as well as controls), AA was analyzed in combination with the CA genotype group. As we have previously observed gender-based differences in genotype frequencies of rs35829419 (unpublished observation), we stratified the patients with sporadic MM and their controls based on gender and found the presence of at least one A allele to be more frequent among male patients (20\%) than in male controls (10\%) $(\mathrm{p}=0.005$, OR 2.22, CI 1.273.86) (Table III). No corresponding risk was detected among women.

Stratifying the patients by melanoma type, i.e. NM versus SSM, revealed a significantly increased risk for developing NM in the presence of least one A allele ( $\mathrm{p}=0.007$, OR 2.89, CI 1.33-6.30) (Table IV). Furthermore, upon stratifying the patient group by gender (Table IV), a higher frequency of the A allele was observed among the male patients (20\%) as compared to the female patients (12\%). This difference, however, did not reach statistical significance ( $\mathrm{p}=0.069$, OR 1.89, CI 0.95-3.76). Furthermore, an even higher risk was associated with the male NM patients ( $\mathrm{p}=0.010, \mathrm{OR} 4.03, \mathrm{CI}$ 1.40-11.59). The other types of melanoma (ALM, LMM) were not analyzed due to their small numbers.

The additional SNP studied in NLRP3, rs10733113, revealed no associations even after stratifications for the clinical parameters (all p-values >0.05) (Table III). However, the logistic regression analysis demonstrated that the combined genotypes rs35829419 and rs10733113 (CA,AA/GA,AA) were significantly more frequent in subjects with sporadic MM than in controls ( $\mathrm{p}=0.001$, OR 2.93, CI 1.585.44) suggesting a synergistic effect.

No overall association was found between the CARD-8 SNP rs2043211 and MM. Moreover, no significant association was found after stratification for gender and melanoma type.

Statistical analyses of the three polymorphisms in relation to skin type (I+II to III+IV), eye color (blue+green to brown+mixed), Breslow thickness $(\geq 2 \mathrm{~mm}$ to $<2 \mathrm{~mm})$, age at diagnosis $(\leq 35,36-60$, 
$>60$ years), and anatomic tumor site (sun exposed to rarely/not sun exposed) were performed, however no associations were found.

NLRP1 polymorphisms in patients with sporadic MM

No significant overrepresentation of the NLRPI SNPs was found in patients with sporadic MM when comparing with the control population (Table II). An overrepresentation of the A allele (TA/AA genotype) in the rs12150220 was observed in the patient group, which did not reach statistical significance ( $\mathrm{p}=0.06$, OR 1.37, CI 0.99-1.89).

When stratifying according to skin type, a 1.85 fold increased risk for MM was seen for the A allele in the rs12150220 among individuals with the fair skin types (type I and II) ( $\mathrm{p}=0.037$, OR 1.85, CI 1.043.33) (Table V). This risk further increased to 3.06-fold when analyzed only in the female patients ( $\mathrm{p}=0.049$, CI 1.01-0.09). No association was observed in the respective group of males.

Upon stratification by melanoma type, no association of any of the NLPRI SNPs was found (Table V). However, when analyzing based on gender, a strongly increased risk for developing NM was found for the rs12150220A allele among females ( $\mathrm{p}=0.020$, OR 6.03, CI 1.33-25). This increased risk was not detected in males.

Statistical analyses of both the NLRP1 polymorphisms in relation to eye color, Breslow thickness, age of diagnosis, and anatomic tumor site of the body were performed, without statistically significant differences. 


\section{Discussion}

The current study has investigated the association of the SNP's rs35829419 and rs10733113 in NLRP3, rs2043211 in CARD-8, and rs6502867 and rs12150220 in NLRP1 in patients with sporadic MM. NLRP3 is a quite recently described member of the NLR family that is an essential regulator of the innate immune responses. NLRP3 forms an inflammatory complex called the inflammasome, which activates caspase- 1 that subsequently leads to the formation of the potent proinflammatory cytokines IL-1 $\beta$ and IL-18. Missense alterations in NLRP3 are postulated to confer a gain of function resulting in uncontrolled production of IL-1 $\beta$, as seen in the patients with hereditary periodic fevers (Aksentijevich et al., 2002). The rs35829419 (Q705K) in NLRP3, due to its prevalence in the healthy population was initially described as a low-penetrance polymorphism (Aksentijevich et al., 2007) but in recent years this SNP has been associated with chronic inflammatory conditions. These associations have especially been seen in combination with rs2043211 in CARD-8 (Verma et al., 2008, Kastbom et al., 2008, Schoultz et al., 2009, Roberts et al., Roberts et al., 2011). Using genetic construct for rs35829419 in an in vitro functional model, we have recently shown this SNP to confer a gain of function in terms of increased spontaneous IL-1 $\beta$ production from a human monocyte cell line (Verma, 2012).

In this study we found an increased overall risk for sporadic MM susceptibility among Swedish males carrying rs35829419A in NLRP3. The combination of rs35829419A with rs2043211 displayed no further increase in susceptibility risk for MM. Notably, a strong association was observed between NM and NLRP3 rs35829419. Unlike SSM which initially describes a radial growth pattern, NM arises rapidly and grows in a more vertical direction and might be associated with a worse prognosis (Pollack et al., 2011). We hypothesize that this gain of function SNP due to increased IL-1 $\beta$ levels, might upregulate other related pro-inflammatory genes like TNF- $\alpha$ and NF- $\kappa \mathrm{B}$ through a positive feed-back loop, which might promote melanoma cells to resist elimination by the $\mathrm{T}$ lymphocytes. This survival phenomenon has previously been demonstrated in melanoma cell lines treated with cytokines like TNF- $\alpha$ (Englaro et al., 1999) and very recently IL-1 $\beta$ (Kholmanskikh et al., 2010).

The fact that the SNP rs35829419A constituted a susceptibility risk only in the male population has previously been observed by us in Crohn's disease (Schoultz et al., 2009). It is tempting to speculate that this differential risk pattern might depend upon the differences in estrogen levels, since the estrogen receptor by acting as a co-factor for NF-kB can inhibit its signaling (Biswas et al., 2005). Moreover, estradiol augments IL-1 $\beta$ mediated pro-inflammatory response by downregulating the IL-1 receptor type-1, probably accounting for an increased tolerance level in females (Schaefer et al., 2005). 
NLRP1 polymorphisms are strongly associated with increased predisposition to autoimmune diseases (Jin et al., 2007b, Jin et al., 2007a). We report an increased risk with the rs12150220 variant in the individuals with a fair skin. Intriguingly, unlike our previous observation, this SNP was found to constitute a risk only in the females. NLRP1 inflammasome activates caspase-5 in addition to caspase1. Caspase-5 is an upstream activator of caspase- 1 and hypothetically, these two caspases together would result in a more effective IL-1 $\beta$ processing. Jin and colleagues have reported several NLRP1 variants (including rs6502867 and rs12150220), that confer susceptibility to autoimmune and autoinflammatory diseases that are associated with vitiligo (Jin et al., 2007b). The fact that the SNP rs121150220 (L155H) is highly conserved through primate evolution (human, chimpanzee, Rhesus Monkey and Bush Baby) (Jin et al., 2007b), indicates that this region is critical for the function of the NLRP1 protein. This region has also been implicated in NOD2-NLRP1 interaction (Wagner et al., 2009). Functional studies elucidating the role of rs 12150220 are lacking but it is tempting to speculate that this SNP leads to an overactivation of the inflammasome and hence contributes to melanoma predisposition.

This is the first study, to our knowledge, showing inflammasome polymorphisms to be associated with tumor susceptibility and melanoma type. Many cancers are known to arise from sites with inflammation (Mantovani et al., 2008). In addition, IL-1 $\beta$ is also detected in various tumor types (Jin et al., 1997, Culig et al., 1998, Oelmann et al., 1997, Saijo et al., 2002), where its expression is associated with tumor invasiveness and angiogenesis (Voronov et al., 2003, Carmi et al., 2009), suggesting a possible role for the inflammasome in tumorgenesis. In line with this, late stage human melanoma cells were demonstrated to spontaneously secrete active IL-1 $\beta$ via constitutive activation of the NLRP3 inflammasome in the absence of exogenous stimulation, exhibiting a feature of autoinflammatory diseases (Okamoto et al., 2010). We hence postulated that the gain of function SNP due to increased IL-1 $\beta$ production might contribute towards increased melanoma susceptibility. In a recent study using a mouse melanoma model it was demonstrated that inflammasomes contributed towards inhibition of the endogenous antitumor response and facilitated tumor growth (van Deventer et al., 2010). Further, in the highly invasive melanoma cells the expression of matrix metalloproteinase-1 (MMP), which is essential for tumor invasion and metastasis, is seen to be increased in an IL-1 $\alpha$ and FGF2 dependent manner (Loffek et al., 2005). Notably, both IL-1 $\alpha$ and FGF2 are regulated by caspase-1 activity (Keller et al., 2008), providing further support for the role of inflammasomes in melanoma. IL-18, another cytokine associated with inflammasome has been shown to be highly expressed in malignant skin tumors (Park et al., 2001), further emphasizing the role of inflammasomes in tumorgenesis.

Additional support for a critical role of IL-1 $\beta$ in the tumor microenvironment is evident by the success of IL-1 blockade in preventing angiogenesis and metastasis in animal models (Chirivi et al., 1993, 
Vidal-Vanaclocha et al., 1994, Vidal-Vanaclocha et al., 1996, Carmi et al., 2009) as well as in human melanoma cell lines (Okamoto et al., 2010, Chirivi et al., 1993). A recent paper demonstrated increased IL-1 $\beta$ expression in primary and metastatic human melanomas and a decrease in melanoma cell growth was observed upon blocking the IL-1 signaling pathway (Qin et al., 2011). A potential role of IL-1 $\beta$ and inflammasomes in the pathogenesis of melanoma has recently been postulated (Zitvogel et al., 2012, Dunn et al., 2012). Above reports suggests that targeting IL-1 in tumors might indeed be a promising therapeutic option.

One caveat of the present study is the small number of patients resulting from sub-group analyses. However, we believe that the consistent trends in our results allow for the conclusion that NLRP3/NLRP1 polymorphisms influence susceptibility to MM and the development of NM.

In conclusion, we report inflammasome polymorphisms to be one link between innate immunity and susceptibility to sporadic MM. Further investigations are needed to confirm this finding on additional cohorts and elucidation of the importance of NLRP proteins in the pathogenesis of melanoma and other cancer types are warranted. 


\section{Acknowledgements and financial support}

We thank Ms. Mona-Lisa Sandh for technical support. Funding for this study was provided by grants from the Medical Research Council of Southeast Sweden (FORSS-8984), the County Council of Östergötland, the Swedish Research Council (PS, K2010-55X-20451-04-03) and the Welander Finsen Foundation. The funders had no role in study design, data collection and analysis, decision to publish, or preparation of the manuscript. 


\section{References}

AGOSTINI, L., MARTINON, F., BURNS, K., MCDERMOTT, M. F., HAWKINS, P. N. \& TSCHOPP, J. 2004. NALP3 forms an IL-1beta-processing inflammasome with increased activity in Muckle-Wells autoinflammatory disorder. Immunity, 20, 319-25.

AKSENTIJEVICH, I., C, D. P., REMMERS, E. F., MUELLER, J. L., LE, J., KOLODNER, R. D., MOAK, Z., CHUANG, M., AUSTIN, F., GOLDBACH-MANSKY, R., HOFFMAN, H. M. \& KASTNER, D. L. 2007. The clinical continuum of cryopyrinopathies: novel CIAS1 mutations in North American patients and a new cryopyrin model. Arthritis Rheum, 56, 1273-85.

AKSENTIJEVICH, I., NOWAK, M., MALLAH, M., CHAE, J. J., WATFORD, W. T., HOFMANN, S. R., STEIN, L., RUSSO, R., GOLDSMITH, D., DENT, P., ROSENBERG, H. F., AUSTIN, F., REMMERS, E. F., BALOW, J. E., JR., ROSENZWEIG, S., KOMAROW, H., SHOHAM, N. G., WOOD, G., JONES, J., MANGRA, N., CARRERO, H., ADAMS, B. S., MOORE, T. L., SCHIKLER, K., HOFFMAN, H., LOVELL, D. J., LIPNICK, R., BARRON, K., O'SHEA, J. J., KASTNER, D. L. \& GOLDBACH-MANSKY, R. 2002. De novo CIAS1 mutations, cytokine activation, and evidence for genetic heterogeneity in patients with neonatal-onset multisystem inflammatory disease (NOMID): a new member of the expanding family of pyrin-associated autoinflammatory diseases. Arthritis Rheum, 46, 3340-8.

BISWAS, D. K., SINGH, S., SHI, Q., PARDEE, A. B. \& IGLEHART, J. D. 2005. Crossroads of estrogen receptor and NF-kappaB signaling. Sci STKE, 2005, pe27.

CARMI, Y., VORONOV, E., DOTAN, S., LAHAT, N., RAHAT, M. A., FOGEL, M., HUSZAR, M., WHITE, M. R., DINARELLO, C. A. \& APTE, R. N. 2009. The role of macrophage-derived IL-1 in induction and maintenance of angiogenesis. J Immunol, 183, 4705-14.

CHIRIVI, R. G., GAROFALO, A., PADURA, I. M., MANTOVANI, A. \& GIAVAZZI, R. 1993. Interleukin 1 receptor antagonist inhibits the augmentation of metastasis induced by interleukin 1 or lipopolysaccharide in a human melanoma/nude mouse system. Cancer Res, 53, 5051-4.

CLEVERS, H. 2004. At the crossroads of inflammation and cancer. Cell, 118, 671-4.

COUSSENS, L. M. \& WERB, Z. 2001. Inflammatory cells and cancer: think different! J Exp Med, 193, F23-6.

COUSSENS, L. M. \& WERB, Z. 2002. Inflammation and cancer. Nature, 420, 860-7.

CULIG, Z., HOBISCH, A., HEROLD, M., HITTMAIR, A., THURNHER, M., EDER, I. E., CRONAUER, M. V., RIESER, C., RAMONER, R., BARTSCH, G., KLOCKER, H. \& KONWALINKA, G. 1998. Interleukin 1 beta mediates the modulatory effects of monocytes on LNCaP human prostate cancer cells. Br J Cancer, 78, 1004-11.

DIEPGEN, T. L. \& MAHLER, V. 2002. The epidemiology of skin cancer. Br J Dermatol, 146 Suppl 61, 1-6.

DUNN, J. H., ELLIS, L. Z. \& FUJITA, M. 2012. Inflammasomes as molecular mediators of inflammation and cancer: potential role in melanoma. Cancer Lett, 314, 24-33.

ENGLARO, W., BAHADORAN, P., BERTOLOTTO, C., BUSCA, R., DERIJARD, B., LIVOLSI, A., PEYRON, J. F., ORTONNE, J. P. \& BALLOTTI, R. 1999. Tumor necrosis factor alpha-mediated inhibition of melanogenesis is dependent on nuclear factor kappa B activation. Oncogene, 18, 1553-9.

FITZPATRICK, T. B. 1988. The validity and practicality of sun-reactive skin types I through VI. Arch Dermatol, 124, 869-71.

FONTALBA, A., GUTIERREZ, O., LLORCA, J., MATEO, I., BERCIANO, J., FERNANDEZ-LUNA, J. L. \& COMBARROS, O. 2008. Deficiency of CARD8 is associated with increased Alzheimer's disease risk in women. Dement Geriatr Cogn Disord, 26, 247-50.

HOFFMAN, H. M. \& SIMON, A. 2009. Recurrent febrile syndromes: what a rheumatologist needs to know. Nat Rev Rheumatol, 5, 249-56.

JIN, L., YUAN, R. Q., FUCHS, A., YAO, Y., JOSEPH, A., SCHWALL, R., SCHNITT, S. J., GUIDA, A., HASTINGS, H. M., ANDRES, J., TURKEL, G., POLVERINI, P. J., GOLDBERG, I. D. \& ROSEN, E. M. 1997. Expression of interleukin-1beta in human breast carcinoma. Cancer, 80, 421-34.

JIN, Y., BIRLEA, S. A., FAIN, P. R. \& SPRITZ, R. A. 2007a. Genetic variations in NALP1 are associated with generalized vitiligo in a Romanian population. J Invest Dermatol, 127, 2558-62. 
JIN, Y., MAILLOUX, C. M., GOWAN, K., RICCARDI, S. L., LABERGE, G., BENNETT, D. C., FAIN, P. R. \& SPRITZ, R. A. 2007b. NALP1 in vitiligo-associated multiple autoimmune disease. N Engl J Med, 356, 1216-25.

KASTBOM, A., VERMA, D., ERIKSSON, P., SKOGH, T., WINGREN, G. \& SODERKVIST, P. 2008. Genetic variation in proteins of the cryopyrin inflammasome influences susceptibility and severity of rheumatoid arthritis (the Swedish TIRA project). Rheumatology (Oxford), 47, 415-7.

KELLER, M., RUEGG, A., WERNER, S. \& BEER, H. D. 2008. Active caspase-1 is a regulator of unconventional protein secretion. Cell, 132, 818-31.

KHOLMANSKIKH, O., VAN BAREN, N., BRASSEUR, F., OTTAVIANI, S., VANACKER, J., ARTS, N., VAN DER BRUGGEN, P., COULIE, P. \& DE PLAEN, E. 2010. Interleukins 1alpha and 1beta secreted by some melanoma cell lines strongly reduce expression of MITF-M and melanocyte differentiation antigens. Int J Cancer, 127, 1625-36.

LENS, M. B. \& DAWES, M. 2004. Global perspectives of contemporary epidemiological trends of cutaneous malignant melanoma. Br J Dermatol, 150, 179-85.

LOFFEK, S., ZIGRINO, P., ANGEL, P., ANWALD, B., KRIEG, T. \& MAUCH, C. 2005. High invasive melanoma cells induce matrix metalloproteinase-1 synthesis in fibroblasts by interleukin1alpha and basic fibroblast growth factor-mediated mechanisms. J Invest Dermatol, 124, 63843.

MANTOVANI, A., ALLAVENA, P., SICA, A. \& BALKWILL, F. 2008. Cancer-related inflammation. Nature, 454, 436-44.

MARTINON, F., BURNS, K. \& TSCHOPP, J. 2002. The inflammasome: a molecular platform triggering activation of inflammatory caspases and processing of prolL-beta. Mol Cell, 10, 417-26.

OELMANN, E., KRAEMER, A., SERVE, H., REUFI, B., OBERBERG, D., PATT, S., HERBST, H., STEIN, H., THIEL, E. \& BERDEL, W. E. 1997. Autocrine interleukin-1 receptor antagonist can support malignant growth of glioblastoma by blocking growth-inhibiting autocrine loop of interleukin1. Int J Cancer, 71, 1066-76.

OKAMOTO, M., LIU, W., LUO, Y., TANAKA, A., CAI, X., NORRIS, D. A., DINARELLO, C. A. \& FUJITA, M. 2010. Constitutively active inflammasome in human melanoma cells mediating autoinflammation via caspase-1 processing and secretion of interleukin-1beta. J Biol Chem, 285, 6477-88.

PARK, H., BYUN, D., KIM, T. S., KIM, Y. I., KANG, J. S., HAHM, E. S., KIM, S. H., LEE, W. J., SONG, H. K., YOON, D. Y., KANG, C. J., LEE, C., HOUH, D., KIM, H., CHO, B., KIM, Y., YANG, Y. H., MIN, K. H. \& CHO, D. H. 2001. Enhanced IL-18 expression in common skin tumors. Immunol Lett, 79, 215-9.

PATHAN, N., MARUSAWA, H., KRAJEWSKA, M., MATSUZAWA, S., KIM, H., OKADA, K., TORII, S., KITADA, S., KRAJEWSKI, S., WELSH, K., PIO, F., GODZIK, A. \& REED, J. C. 2001. TUCAN, an antiapoptotic caspase-associated recruitment domain family protein overexpressed in cancer. J Biol Chem, 276, 32220-9.

POLLACK, L. A., LI, J., BERKOWITZ, Z., WEIR, H. K., WU, X. C., AJANI, U. A., EKWUEME, D. U., LI, C. \& POLLACK, B. P. 2011. Melanoma survival in the United States, 1992 to 2005. J Am Acad Dermatol, 65, S78-86.

QIN, Y., EKMEKCIOGLU, S., LIU, P., DUNCAN, L. M., LIZEE, G., POINDEXTER, N. \& GRIMM, E. A. 2011. Constitutive aberrant endogenous interleukin-1 facilitates inflammation and growth in human melanoma. Mol Cancer Res, 9, 1537-50.

RAZMARA, M., SRINIVASULA, S. M., WANG, L., POYET, J. L., GEDDES, B. J., DISTEFANO, P. S., BERTIN, J. \& ALNEMRI, E. S. 2002. CARD-8 protein, a new CARD family member that regulates caspase-1 activation and apoptosis. J Biol Chem, 277, 13952-8.

ROBERTS, R. L., TOPLESS, R. K., PHIPPS-GREEN, A. J., GEARRY, R. B., BARCLAY, M. L. \& MERRIMAN, T. R. Evidence of interaction of CARD8 rs2043211 with NALP3 rs35829419 in Crohn's disease. Genes Immun, 11, 351-6. 
ROBERTS, R. L., VAN RIJ, A. M., PHILLIPS, L. V., YOUNG, S., MCCORMICK, S. P., MERRIMAN, T. R. \& JONES, G. T. 2011. Interaction of the inflammasome genes CARD8 and NLRP3 in abdominal aortic aneurysms. Atherosclerosis.

SAIJO, Y., TANAKA, M., MIKI, M., USUI, K., SUZUKI, T., MAEMONDO, M., HONG, X., TAZAWA, R., KIKUCHI, T., MATSUSHIMA, K. \& NUKIWA, T. 2002. Proinflammatory cytokine IL-1 beta promotes tumor growth of Lewis lung carcinoma by induction of angiogenic factors: in vivo analysis of tumor-stromal interaction. $J$ Immunol, 169, 469-75.

SCHAEFER, T. M., WRIGHT, J. A., PIOLI, P. A. \& WIRA, C. R. 2005. IL-1beta-mediated proinflammatory responses are inhibited by estradiol via down-regulation of IL-1 receptor type I in uterine epithelial cells. J Immunol, 175, 6509-16.

SCHOULTZ, I., VERMA, D., HALFVARSSON, J., TORKVIST, L., FREDRIKSON, M., SJOQVIST, U., LORDAL, M., TYSK, C., LERM, M., SODERKVIST, P. \& SODERHOLM, J. D. 2009. Combined polymorphisms in genes encoding the inflammasome components NALP3 and CARD8 confer susceptibility to Crohn's disease in Swedish men. Am J Gastroenterol, 104, 1180-8.

SCHRODER, K. \& TSCHOPP, J. 2010. The inflammasomes. Cell, 140, 821-32.

SYNNERSTAD, I., NILSSON, L., FREDRIKSON, M. \& ROSDAHL, I. 2004. Frequency and distribution pattern of melanocytic naevi in Swedish 8-9-year-old children. Acta Derm Venereol, 84, 2716.

TU, C. X., GU, J. S. \& LIN, X. R. 2003. Increased interleukin-6 and granulocyte-macrophage colony stimulating factor levels in the sera of patients with non-segmental vitiligo. J Dermatol Sci, 31, 73-8.

WAGNER, R. N., PROELL, M., KUFER, T. A. \& SCHWARZENBACHER, R. 2009. Evaluation of Nod-like receptor (NLR) effector domain interactions. PLOS ONE, 4, e4931.

VAN DEVENTER, H. W., BURGENTS, J. E., WU, Q. P., WOODFORD, R. M., BRICKEY, W. J., ALLEN, I. C., MCELVANIA-TEKIPPE, E., SERODY, J. S. \& TING, J. P. 2010. The inflammasome component NLRP3 impairs antitumor vaccine by enhancing the accumulation of tumor-associated myeloid-derived suppressor cells. Cancer Res, 70, 10161-9.

VERMA, D., LERM, M., BLOMGRAN JULINDER, R., ERIKSSON, P., SODERKVIST, P. \& SARNDAHL, E. 2008. Gene polymorphisms in the NALP3 inflammasome are associated with interleukin-1 production and severe inflammation: relation to common inflammatory diseases? Arthritis Rheum, 58, 888-94.

VERMA, D., SARNDAHL, E., ANDERSSON, H., ERIKSSON, P., FREDRIKSON, M., JONSSON, J.I., LERM, M., SÖDERKVIST, P. 2012. The Q705K polymorphism in NLRP3 is a gain-of-function alteration leading to excessive interleukin-1B and IL-18 production. PLOS ONE. In Press.

VIDAL-VANACLOCHA, F., ALVAREZ, A., ASUMENDI, A., URCELAY, B., TONINO, P. \& DINARELLO, C. A. 1996. Interleukin 1 (IL-1)-dependent melanoma hepatic metastasis in vivo; increased endothelial adherence by IL-1-induced mannose receptors and growth factor production in vitro. J Nat/ Cancer Inst, 88, 198-205.

VIDAL-VANACLOCHA, F., AMEZAGA, C., ASUMENDI, A., KAPLANSKI, G. \& DINARELLO, C. A. 1994. Interleukin-1 receptor blockade reduces the number and size of murine B16 melanoma hepatic metastases. Cancer Res, 54, 2667-72.

VILLANI, A. C., LEMIRE, M., FORTIN, G., LOUIS, E., SILVERBERG, M. S., COLLETTE, C., BABA, N., LIBIOULLE, C., BELAICHE, J., BITTON, A., GAUDET, D., COHEN, A., LANGELIER, D., FORTIN, P. R., WITHER, J. E., SARFATI, M., RUTGEERTS, P., RIOUX, J. D., VERMEIRE, S., HUDSON, T. J. \& FRANCHIMONT, D. 2009. Common variants in the NLRP3 region contribute to Crohn's disease susceptibility. Nat Genet, 41, 71-6.

VORONOV, E., SHOUVAL, D. S., KRELIN, Y., CAGNANO, E., BENHARROCH, D., IWAKURA, Y., DINARELLO, C. A. \& APTE, R. N. 2003. IL-1 is required for tumor invasiveness and angiogenesis. Proc Natl Acad Sci U S A, 100, 2645-50.

ZITVOGEL, L., KEPP, O., GALLUZZI, L. \& KROEMER, G. 2012. Inflammasomes in carcinogenesis and anticancer immune responses. Nat Immunol, 13, 343-51. 


\section{Tables}

Table I.

\begin{tabular}{|c|c|c|}
\hline \multicolumn{3}{|c|}{ Patients with sporadic malignant melanoma and control } \\
\hline & Patients & Controls \\
\hline & 258 & 792 \\
\hline $\begin{array}{l}\text { Total number } \\
\text { Sex: males }\end{array}$ & $120(47 \%)$ & $396(50 \%)$ \\
\hline females & $138(53 \%)$ & $396(50 \%)$ \\
\hline Mean age & $59 \pm 14$ & $54 \pm 17$ \\
\hline Mean age at diagnosis & $55 \pm 15$ & - \\
\hline \multicolumn{3}{|c|}{ Phenotype features of the patients and melanoma characteristics } \\
\hline \multicolumn{3}{|c|}{ Number } \\
\hline \multicolumn{3}{|l|}{ Age at diagnosis } \\
\hline \multicolumn{2}{|l|}{$\leq 35$} & $27(11 \%)$ \\
\hline \multicolumn{2}{|l|}{$36-60$} & $129(54 \%)$ \\
\hline \multicolumn{2}{|l|}{$>60$} & $84(35 \%)$ \\
\hline \multicolumn{3}{|l|}{ Skin type* } \\
\hline \multicolumn{2}{|l|}{$1+I 1$} & $153(60 \%)$ \\
\hline \multicolumn{2}{|l|}{ III+IV } & $100(40 \%)$ \\
\hline \multicolumn{3}{|l|}{ Eye color } \\
\hline \multicolumn{2}{|l|}{ Blue + green } & $211(82 \%)$ \\
\hline \multicolumn{2}{|l|}{ Brown + mixed } & $46(18 \%)$ \\
\hline \multicolumn{3}{|l|}{ Hair color } \\
\hline \multicolumn{2}{|l|}{ Blond + red } & $216(84 \%)$ \\
\hline \multicolumn{2}{|l|}{ Brown + Black } & $40(16 \%)$ \\
\hline \multicolumn{3}{|l|}{ Histopathological type } \\
\hline \multicolumn{2}{|c|}{ Superficial spreading melanoma (SSM) } & $150(64 \%)$ \\
\hline \multicolumn{2}{|c|}{ Nodular melanoma (NM) } & $53(22 \%)$ \\
\hline \multicolumn{2}{|c|}{ Lentigo malignant melanoma ( LMM) } & $9(4 \%)$ \\
\hline \multicolumn{2}{|c|}{ Acro-lentiginous melanoma (ALM) } & $2(1 \%)$ \\
\hline \multicolumn{2}{|c|}{ Melanoma in situ } & $22(9 \%)$ \\
\hline \multicolumn{3}{|l|}{ Breslow thickness (mm) } \\
\hline \multicolumn{2}{|l|}{$<2$} & $166(77 \%)$ \\
\hline \multicolumn{2}{|l|}{$\geq 2$} & $50(23 \%)$ \\
\hline Anatomic site & & \\
\hline Sun exposed areas & & $176(72 \%)$ \\
\hline Rarely/ not-sun expose & areas & $37(15 \%)$ \\
\hline Other areas & & $33(13 \%)$ \\
\hline
\end{tabular}

*Skin type I+11, Sun-sensitive skin type, Skin type III +IV, Less sun-sensitive skin type 
Table II. Distribution of genotypes.

\begin{tabular}{|lll|}
\hline & Sporadic MM & Controls \\
\hline NLRP3 rs 35829419 & 257 & 792 \\
CC & $218(85 \%)$ & $692(87 \%)$ \\
CA & $36(14 \%)$ & $94(12 \%)$ \\
AA & $3(1 \%)$ & $6(1 \%)$ \\
\hline NLRP3 rs 10733113 & 257 & 792 \\
GG & $181(71 \%)$ & $574(72 \%)$ \\
GA & $70(27 \%)$ & $204(26 \%)$ \\
AA & $6(2 \%)$ & $14(2 \%)$ \\
\hline NLRP1 rs 6502867 & 255 & 784 \\
TT & $169(66 \%)$ & $497(63 \%)$ \\
TC & $80(31 \%)$ & $248(32 \%)$ \\
CC & $6(3 \%)$ & $39(5 \%)$ \\
\hline NLRP1 rs 12150220 & 254 & 790 \\
TT & $66(26 \%)$ & $157(20 \%)$ \\
TA & $132(52 \%)$ & $410(52 \%)$ \\
AA & $56(22 \%)$ & $223(28 \%)$ \\
\hline CARD-8 rs 2043211 & 257 & 792 \\
TT & $114(44 \%)$ & $330(42 \%)$ \\
TA & $111(43 \%)$ & $359(45 \%)$ \\
AA & $32(13 \%)$ & $103(13 \%)$ \\
\hline
\end{tabular}


Table III. NLRP3 rs35829419 and NLRP3 rs10733113 genotype distributions in patients with sporadic MM. Genotype distributions for the two SNPs are also represented after gender stratification and in combination.

\begin{tabular}{|c|c|c|c|c|}
\hline Genotypes & Sporadic MM & Controls & OR $(95 \% \mathrm{Cl})$ & $P$ value \\
\hline NLRP3 rs35829419 & 257 & 792 & & \\
\hline CC & $218(85 \%)$ & $692(87 \%)$ & 1 & \\
\hline CA/AA & $39(15 \%)$ & $100(13 \%)$ & $1.27(0.86-1.88)$ & 0.22 \\
\hline \multicolumn{5}{|l|}{$\begin{array}{l}\text { NLRP3 rs35829419 } \\
\text { males }\end{array}$} \\
\hline CC & $96(80 \%)$ & 355 (90\%) & 1 & \\
\hline CA/AA & $24(20 \%)$ & $40(10 \%)$ & $2.22(1.27-3.86)$ & 0.005 \\
\hline \multicolumn{5}{|l|}{ females } \\
\hline CC & $121(88 \%)$ & 337 (85\%) & 1 & \\
\hline CA/AA & $16(12 \%)$ & $60(15 \%)$ & $0.74(0.41-1.34)$ & 0.32 \\
\hline NLRP3 rs10733113 & 257 & 792 & & \\
\hline GG & $181(70 \%)$ & $574(72 \%)$ & 1 & \\
\hline GA/AA & $76(30 \%)$ & 218 ( $28 \%)$ & $1.13(0.83-1.53)$ & 0.44 \\
\hline \multicolumn{5}{|l|}{ NLRP3 rs10733113 } \\
\hline males & 120 & 395 & & \\
\hline CC & 87 (73\%) & 287 (73\%) & 1 & \\
\hline CA/AA & $33(27 \%)$ & $108(27 \%)$ & $1.01(0.64-1.59)$ & 0.97 \\
\hline females & 137 & 397 & & \\
\hline CC & 94 (69\%) & 287 (72\%) & 1 & \\
\hline CA/AA & $43(31 \%)$ & $110(28 \%)$ & $1.19(0.78-1.82)$ & 0.41 \\
\hline \multicolumn{5}{|c|}{ NLRP3 rs 35829419/rs 10733113} \\
\hline $\mathrm{CC} / \mathrm{GG}$ & $169(92 \%)$ & 496 (87\%) & 1 & \\
\hline$C A+A A / G A+A A$ & $22(8 \%)$ & $22(13 \%)$ & $2.93(1.58-5.44)$ & 0.001 \\
\hline
\end{tabular}


Table IV. NLRP3 rs35829419 genotype distribution in patients with sporadic MM upon stratifying for gender and melanoma type.

\begin{tabular}{|llll|}
\hline Stratification & Sporadic MM & OR (95\% Cl) & P value \\
\hline $\begin{array}{l}\text { gender } \\
\text { males/females }\end{array}$ & 257 & & \\
CC & & & \\
CA/AA & $96(80 \%) / 121(88 \%)$ & 1 & 0.069 \\
\hline $\begin{array}{l}\text { Melanoma type } \\
\text { *NM/SSM }\end{array}$ & $24(20 \%) / 16(12 \%)$ & $1.89(0.95-3.76)$ & \\
CC & 203 & & 0.007 \\
CA/AA & $38(72 \%) / 132(88 \%)$ & 1 & \\
\hline gender/melanoma type & $15(28 \%) / 18(12 \%)$ & $2.89(1.33-6.28)$ & \\
males & 203 & & 0.010 \\
NM/SSM & & & \\
CC & & 1 & \\
CA/AA & $16(62 \%) / 58(87 \%)$ & $4.03(1.40-11.59)$ & \\
females & $10(38 \%) / 9(13 \%)$ & & 0.30 \\
NM/SSM & & & \\
CC & & $1.87(0.57-6.16)$ & \\
CA/AA & $22(81 \%) / 74(89 \%)$ & & \\
\hline
\end{tabular}

*NM, Nodular melamona; SSM, Superficial spreading melanoma 
Table V. NLRP1 genotype frequencies in patients with sporadic melanoma and NLRP1 rs 12150220 genotype distribution after stratifying for gender, skin type and melanoma type.

\begin{tabular}{|c|c|c|c|c|}
\hline Genotypes & Sporadic MM & Controls & OR (95\% Cl) & $P$ value \\
\hline NLRP1 rs 6502867 & 255 & 784 & & \\
\hline TT & 169 (66\%) & 497 (63\%) & 1 & \\
\hline $\mathrm{TT} / \mathrm{CC}$ & 86 (34\%) & $287(37 \%)$ & $1.18(0.78-1-59)$ & 0.27 \\
\hline NLRP1 rs 12150220 & 254 & 790 & & \\
\hline TT & $66(26 \%)$ & $157(20 \%)$ & 1 & \\
\hline TA/AA & $188(74 \%)$ & $633(80 \%)$ & 1.37 (0.99-1.89) & 0.06 \\
\hline Stratification & Sporadic MM & OR (95\% Cl) & $P$ value & \\
\hline \multicolumn{5}{|l|}{ Skin type* } \\
\hline$|+| I / I I I+I V$ & $157 / 97$ & & & \\
\hline TT & $32(21 \%) / 32(33 \%)$ & 1 & & \\
\hline TA/AA & $120(79 \%) / 65(67 \%)$ & $1.85(1.04-3.33)$ & 0.037 & \\
\hline \multicolumn{5}{|l|}{ Gender/skin type } \\
\hline Females & $86 / 45$ & & & \\
\hline \multicolumn{5}{|l|}{$|+| I / I I I+I V$} \\
\hline $\mathrm{TT}$ & $20(23 \%) / 16(36 \%)$ & 1 & & \\
\hline TA/AA & $66(77 \%) / 29(64 \%)$ & $3.06(1.01-9.09)$ & 0.049 & \\
\hline Males & $66 / 52$ & & & \\
\hline \multicolumn{5}{|l|}{ I+II/III+IV } \\
\hline TT & $12(18 \%) / 16(31 \%)$ & 1 & & \\
\hline TA/AA & $54(82 \%) / 36(69 \%)$ & $2.00(0.85-4.72)$ & 0.11 & \\
\hline \multicolumn{5}{|l|}{$\begin{array}{l}\text { Gender /melanoma } \\
\text { type }\end{array}$} \\
\hline Females & $27 / 83$ & & & \\
\hline \multicolumn{5}{|l|}{ \#NM/SSM } \\
\hline TT & $2(7 \%) / 27(33 \%)$ & 1 & & \\
\hline TA & $17(63 \%) / 40(48 \%)$ & $5.74(1.22 .27)$ & 0.027 & \\
\hline$A A$ & $8(30 \%) / 16(19 \%)$ & $6.75(1.27-35.7)$ & 0.025 & \\
\hline$T A+A A$ & $25(93 \%) / 56(67 \%)$ & $6.03(1.33-25)$ & 0.025 & \\
\hline Males & $26 / 66$ & & & \\
\hline \multicolumn{5}{|l|}{ NM/SSM } \\
\hline TT & $9(35 \%) / 13(20 \%)$ & 1 & & \\
\hline TA & $10(38 \%) / 35$ (53\%) & $0.41(0.14-1.24)$ & 0.12 & \\
\hline AA & $7(27 \%) / 18(27 \%)$ & $0.56(0.17-1.90)$ & 0.35 & \\
\hline$T A+A A$ & $17(65 \%) / 53 \%(80 \%)$ & $0.46(0.17-1.27)$ & 0.14 & \\
\hline
\end{tabular}

*Skin type I+II, Sun-sensitive; III+IV, Less sun-sensitive.

\#NM, Nodular melanoma; SSM, Superficial spreading melanoma 


\section{Figure 1.}

\section{A simplified picture of IL-1 $\beta$ and IL-18 processing by the NLRP1 and NLRP3 inflammasomes.}

Upon sensing a stimuli, NLRP1/NLRP3 recruits the adaptor protein ASC and thereby activates caspase 1 (and caspase 5 in case of NLRP1), which cleaves pro IL-1 $\beta$ and pro IL-18 to form the mature IL-1 $\beta$ and IL-18. These pro-inflammatory cytokines are then secreted out of the cell and upregulate a number of pro-inflammatory genes through a positive feedback loop. CARD-8 is postulated to be a binding partner of NLRP3, whereas its binding is not required by NLRP1 which already contains a CARD-8 domain. 